\title{
Reply to "Reply to comments on defining biominerals and organominerals: Direct and indirect indicators of life [Perry et al., Sedimentary Geology, 201, 157-179]” by R.S. Perry and M.A. Sephton: [Sedimentary Geology 213 (2009) 156]
}

\author{
Christian Défarge $^{\mathrm{a}, \mathrm{b}}$, Pascale Gautret ${ }^{\mathrm{a}}$ Joachim Reitner $^{\mathrm{c}}$ and Jean Trichet $^{\mathrm{a}}$ \\ a Université d'Orléans, CNRS/INSU, Université François-Rabelais Tours, Institut des \\ Sciences de la Terre d'Orléans-UMR 6113, Campus Géosciences, 1A rue de la Férollerie, \\ 45071 Orléans cedex 2, France

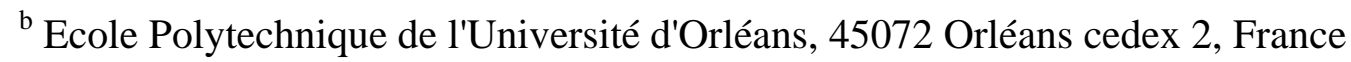 \\ ${ }^{\mathrm{c}}$ Göttingen Zentrum Geowissenschaften, Abteilung Geobiologie, Universität Göttingen, \\ Goldschmidtstrasse 3, D-37077 Göttingen, Germany
}

\begin{abstract}
This is a reply to R.S. Perry and M.A. Sephton's "Reply to comments on defining biominerals and organominerals: direct and indirect indicators of life [Perry et al., Sedimentary Geology, 201, 157-179]” [Sedimentary Geology 213 (2009) 156].
\end{abstract}

Keywords: Organominerals; Organomineralization; Terminology

The best reply to Perry and Sephton's (2009) reply to comments by (Altermann et al., 2009) and (Défarge et al., 2009) on the paper by Perry et al. (2007, Defining biominerals and organominerals: direct and indirect indicators of life, Sedimentary Geology 201, 157-179) still remains these very comments, which Perry and Sephton do not seem to have carefully read. However the authors' reply is so remote from the customary practice of scientific discussion that a further answer is called for.

First of all, contrary to all academic custom, Perry and Sephton's reply does not include the least excuse for not having quoted, in Perry et al. (2007), former definitions of organominerals, in particular those given by (Défarge \& Trichet, 1995) and (Trichet \& Défarge, 1995), which they were aware of ([Altermann et al., 2009] and [Défarge et al., 2009]). Moreover they repeat this cavalier attitude in their reply, in which the title of Défarge et al.'s (2009) comment is cited without its incipit "Defining organominerals: [Comments on 'Defining biominerals and organominerals: direct and indirect indicators of life']". Apparently Perry and Sephton find it hard to accept that organominerals have been highlighted, named and defined before them.

As in their original paper (Perry et al., 2007), the examples chosen by Perry and Sephton (2009) to illustrate their 'new' definition of organominerals are unconvincing: glauconite mineral, which is cited as an example of organomineral, can be considered so only when the existence of an organic control on mineral formation has been proved. Glauconite in general 
is no more an organomineral than is, e. g., calcite, which is represented in nature both by organominerals and biominerals, sometimes within the same sediment ([Défarge \& Trichet, 1995] and [Défarge et al., 1996]), and by minerals formed through inorganic processes.

Finally, Perry and Sephton (2009) abruptly claim, without any discussion of former definitions of organominerals or of critical remarks addressed to Perry et al. (2007), that the term 'organomineral' is "now newly defined” (by Perry et al., 2007), although both (Altermann et al., 2009) and (Défarge et al., 2009) have shown that Perry et al.'s paper does not contain a single clear definition of these objects. In accord with Altermann et al. (2009), we persist in considering that Perry et al.'s (2007) 'new' definition of organominerals is unnecessary, unfounded, and introduces confusion that is detrimental to a fine understanding of geobiological and astrobiological processes and products. In these scientific domains, the only valid definition of organominerals that has proved useful until now remains that of (Défarge \& Trichet, 1995) and (Trichet \& Défarge, 1995), as recapped and specified by (Défarge et al., 2009) and (Défarge, in press).

\section{References}

Altermann et al., 2009 W. Altermann, C. Böhmer, F. Gitter, F. Heiman, I. Heller, B. Läuchli and C. Putz, Defining biominerals and organominerals: direct and indirect indicators of life. Perry et al., Sedimentary Geology 201, 157-179, Sedimentary Geology 213 (2009), pp. 150151.

Défarge \& Trichet, 1995 C. Défarge and J. Trichet, From biominerals to 'organominerals’: the example of the modern lacustrine calcareous stromatolites from Polynesian atolls. In: D. Allemand and J.P. Cuif, Editors, Proc. 7th Int. Symp. Biomineralization. Bulletin de l'Institut Océanographique de Monaco, no. spéc. 14 vol. 2 (1995), pp. 265-271.

Défarge et al., 1996 C. Défarge, J. Trichet, A.M. Jaunet, M. Robert, J. Tribble and F.J. Sansone, Texture of microbial sediments revealed by cryo-scanning electron microscopy, Journal of Sedimentary Research 66 (1996), pp. 935-947.

Défarge et al., 2009 C. Défarge, P. Gautret, J. Reitner and J. Trichet, Defining organominerals: comments on 'Defining biominerals and organominerals: direct and indirect indicators of life’ by Perry et al. (2007, Sedimentary Geology 201, 157-179), Sedimentary Geology 213 (2009), pp. 152-155.

Défarge, in press Défarge, C., in press. Organomineralization. In: Reitner, J., Thiel, V. (Eds.), Encyclopedia of Geobiology. Springer, Heidelberg.

Perry \& Sephton, 2009 R.S. Perry and M.A. Sephton, Reply to comments on defining biominerals and organominerals: direct and indirect indicators of life [Perry et al., Sedimentary Geology, 201, 157-159], Sedimentary Geology 213 (2009), p. 156.

Perry et al., 2007 R.S. Perry, N. Mcloughlin, B.Y. Lynne, M.A. Sephton, J.D. Oliver, C.C. Perry, K. Campbell, M.H. Engel, J.D. Farmer, M.D. Brasier and J.T. Staley, Defining biominerals and organominerals: direct and indirect indicators of life, Sedimentary Geology 201 (2007), pp. 157-179. 
Trichet \& Défarge, 1995 J. Trichet and C. Défarge, Non-biologically supported organomineralization. In: D. Allemand and J.P. Cuif, Editors, Proc. 7th Int. Symp.

Biomineralization, Bulletin de l'Institut Océanographique de Monaco, no. spéc. 14 vol. 2 (1995), pp. 203-236. 